\title{
Row over plan to treat plants as 'pesticides'
}

Washington. Eleven scientific societies have criticized proposals by the US Environmental Protection Agency (EPA) to expand its regulatory authority over pesticides to include plants genetically engineered to produce toxic substances.

The EPA published its proposed policy in November 1994, and expects to produce a final version this winter. It defines a "plant pesticide" as "a pesticidal substance produced in a living plant and the genetic material necessary for [its] production". Under the regulation, manufacturers of plant pesticides would be required to apply for EPA permission for late-stage development and marketing.

But the societies that are protesting including the American Institute of Biological Sciences and the American Society for Microbiology - have issued a report calling the EPA's policy "scientifically indefensible" for proposing to regulate genetically-engineered plants under a law intended to monitor externally applied chemical pesticides.

"Genes and the substances encoded by them" are not pesticides, says the report, delivered to Carol Browner, the administrator of the EPA, last week. The authors say that defining them as such would hurt public confidence in food safety, damage US exports, and impose an onerous regulatory burden on small biotechnology companies.

As a result, they claim, small companies and academic researchers would be dis- couraged from developing geneticallyengineered pest-resistant plants. "It's like putting a skull and crossbones on these biotech products," complains James Thornton of Demeter Biotechnologies Ltd, a small North Carolina company that designs genes for disease resistance in plants.

But major industry groups, concerned about the public acceptability of their products, have joined public advocacy groups in opposing such conclusions. "Just because a substance is in a plant doesn't mean that it's safe," says Lynn Goldman, EPA's assistant administrator for prevention, pesticides and toxic substances.

Rebecca Goldburg, a senior scientist at the Environmental Defense Fund, accuses the societies of having a "double standard" for biotechnology, expecting generous

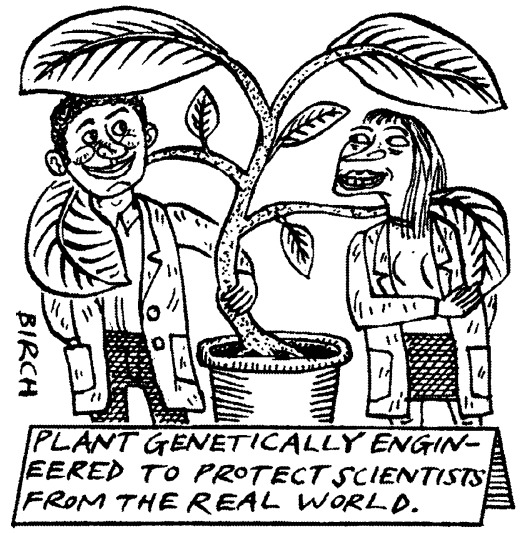

research funding, but avoiding oversight.

The Biotechnology Industry Association (BIO) has voiced its support of the EPA proposal, but has urged the agency to narrow the definition of plant pesticide to include only active pesticidal agents, and not the genetic material that produced them.

A spokesman says that the complaining scientists have misread the Federal Insecticide, Fungicide and Rodenticide Act. "The pesticide law gives EPA very broad authorities to regulate pesticides," says Alan Goldhammer, BIO's director of technical affairs. "It doesn't say that they can't regulate plants."

Other industry groups and companies stress the importance to consumers of regulations such as the one proposed. "A strong government oversight system is important to public confidence," says Loren Wassell, spokesman for Monsanto, the agricultural and chemicals company.

Monsanto was the first company to gain EPA approval for commercial marketing of a plant genetically engineered for pest protection. Its NewLeaf potato, first marketed in 1995, was protected against the Colorado potato beetle by a gene derived from Bacillus thuringiensis, a soil bacterium.

Companies may at present voluntarily submit plants with genetically engineered traits for pest resistance for EPA approval, as did Monsanto. If the new policy is adopted, such approval would become mandatory.

\section{Public spending curbs threaten Israeli research projects}

Jerusalem. New research projects are likely to see their funding reduced as a result of public spending cuts that form part of an anti-inflation programme approved last month by Israel's cabinet.

The full package of cuts - which was called for by the new prime minister, Benyamin Netanyahu - has still to be approved by the Knesset, Israel's parliament. But government officials are already considering how to absorb them with the least damage to research programmes.

Hardest hit is likely to be the Ministry of Science, which funds primarily medium- and long-term research. The cabinet has cancelled a decision by the previous government to increase the ministry's budget, and has reduced its budget for next year by US $\$ 3.5$ million or 7 per cent.

Ministry officials are concerned that the government's commitment to scientific and technological advancement will lose its credibility. "In terms of the message it sends, we'd be happier if the budget were at least growing in a symbolic way," says Moshe Mishal, the ministry's deputy directorgeneral for planning and oversight. "A \$3.5-million slash cuts into the flesh."

About a third of the ministry's budget (which totals $\$ 47$ million this year) goes to special funds and programmes, and another third to joint scientific programmes with other countries. A technological research and development treaty between Israel and the European Union, ratified by the Israeli cabinet last week, requires an annual Israeli contribution of $\$ 30$ million, part of which will come from the ministry's budget.

Ze'ev Binyamin (Benny) Begin, the minister of science - a geologist by training - points out that the funding provided by his ministry is only a small portion of the $\$ 1$ billion that government and industry spend on research and development each year. Nevertheless, the areas that it funds are of importance to Israel's economic and technological advancement.

One institution seriously concerned about the cuts is the Technion - Israel Institute of Technology - where science ministry grants are an important component of the research budget. According to Felix Naggar, head of Technion's project advancement department, the ministry signed research contracts worth $\$ 5.5$ million with his institution last year.

Arnon Bentur, Technion's vice-president for research, says it is too early to say what the effects of the cuts will be. But he is also concerned about expected cuts at the Ministry of Industry and Commerce, whose research budget is likely to be reduced by 4.5 per cent, or $\$ 17$ million.

The industry ministry awards grants to companies and academic scientists for applied research and development. Although the Technion received only $\$ 900,000$ directly from the ministry in 1995 , it benefits in a much larger way indirectly. Many research projects commissioned by Israeli industries or performed jointly by industry and Technion scientists are funded by the ministry.

"In many ways the industry ministry cuts will be harder on us," Bentur explains, because the amounts are larger and because "we have invested in a lot of infrastructure to fulfil the [ministry's] needs." The danger, he says, is that, "after we have bent over backwards to help the ministry, we will be left with infrastructure that won't be used".

Haim Watzman 